Article

\title{
What Prompts Small and Medium Enterprises to Implement CSR? A Qualitative Insight from an Emerging Economy
}

\author{
Zengming Zou ${ }^{1}$, Yu Liu ${ }^{2, *}$, Naveed Ahmad ${ }^{3}{ }^{(0)}$, Muhammad Safdar Sial ${ }^{4}$, Alina Badulescu ${ }^{5}(\mathbb{D}$, \\ Malik Zia-Ud-Din ${ }^{6}$ and Daniel Badulescu ${ }^{5}$ (D)
}

check for

updates

Citation: Zou, Z.; Liu, Y.; Ahmad, N.; Sial, M.S.; Badulescu, A.; Zia-Ud-Din, M.; Badulescu, D. What Prompts Small and Medium Enterprises to Implement CSR? A Qualitative Insight from an Emerging Economy. Sustainability 2021, 13, 952. https://doi.org/10.3390/su13020952

Received: 25 December 2020

Accepted: 16 January 2021

Published: 19 January 2021

Publisher's Note: MDPI stays neutra with regard to jurisdictional claims in published maps and institutional affiliations.

Copyright: (c) 2021 by the authors. Licensee MDPI, Basel, Switzerland. This article is an open access article distributed under the terms and conditions of the Creative Commons Attribution (CC BY) license (https:// creativecommons.org/licenses/by/ $4.0 /)$
1 School of Economics and Management, Wuhan University, Wuhan 430072, China; zouzongming826@163.com 2 School of Economics and Management, Communication University of China, Beijing 100024, China

3 Faculty of Management Studies, University of Central Punjab, Lahore 54000, Pakistan; naveeddgk2010@gmail.com

4 Department of Management Sciences, COMSATS University Islamabad (CUI), Islamabad 44000, Pakistan; safdar.sial786@gmail.com

5 Department of Economics and Business, Faculty of Economic Sciences, University of Oradea, 410087 Oradea, Romania; abadulescu@uoradea.ro (A.B.); dbadulescu@uoradea.ro (D.B.)

6 Department of Law, Islamia University, Bahawalpur 63100, Pakistan; malikziaudin@yahoo.com

* Correspondence: ly1644@163.com

\begin{abstract}
The topic of corporate social responsibility (henceforth referred to as CSR) has been a central topic during the last decade, but the majority of the existing literature discusses CSR relationship with large organizations. Whereas, its contribution in small and medium enterprises (henceforth referred to as SME) sector has received little attention. There have been some studies that focused on CSR activities in SME sector quantitatively in the context of developing economies like Pakistan, but the fact is, to date, SME sector of Pakistan is not participating actively in CSR-related activities due to some constraints. The present study is a pioneer attempt, to explore CSR barriers that restrict SME sector of Pakistan from practicing CSR initiatives. For this reason, the present study explores these barriers qualitatively in order to gain in-depth knowledge of different CSR barriers. In doing so, we conducted semi-structured in-depth interviews from 9 SMEs in Lahore city of Pakistan. We performed thematic analysis, which produced five relevant themes of CSR barriers, including: Lack of resources, lack of regulations, lack of top management commitment, lack of CSR knowledge, and passive customer behavior. Our analysis further showed that lack of resources is the most related barrier that hinder SMEs to be engaged in CSR activities. This paper contributes to CSR literature in emerging economies' context. Through an increased awareness of barriers, policy makers and practitioners may take necessary steps to improve CSR practices in SMEs.
\end{abstract}

Keywords: corporate social responsibility barriers; small and medium enterprises; Pakistan; environmental management

\section{Introduction}

Maybe corporate social responsibility (CSR) is as old as business itself. Many examples of businesses that take CSR for the welfare can be found in the history of the ancient world [1]. With the emergence of industrialization in Europe and migration to other parts of the world, big business has emerged and the debate on social responsibility in the industry has begun. In the 1930s and 1940s, the role of managers and the social function of business began to appear in the literature, and scholars began to discuss specific corporate tasks [2]. The first book on CSR titled "Social responsibility of the businessman" was published in 1953 [3], and since then there had been different debates on the topic of CSR in extant literature. The concept of CSR appealed policy makers around the world, and several policy documents began to emerge from several agencies. One of the references to define CSR in the literature is provided by the World Business Council for Sustainable 
Development (WBCSD), describing CSR as a "sustainable entrepreneurial commitment to contribute to economic development while improving the quality of life of workers and their families and society as a whole" [4]. Carroll [5] proposed a four-dimensional definition of CSR, consisting of economic responsibility, legal responsibility, ethical responsibility, and philanthropic responsibility.

Another important factor in this improvement was the convergence of the researchers and policy makers to the point that social commitment is the responsibility of large businesses [6]. This is probably due to the assumption that large businesses have residual resources and the ability to fulfill certain social obligations. These organizations were considered to be responsible for taking into account the impact of the company's activities on social and environmental conditions, in particular, to consider the liability as beyond the company's responsibilities towards shareholders. Since then, CSR has been recognized at the management level as the introduction and implementation of sustainable development programs. Over time, many theorists began to understand the importance of small and medium enterprises to improve the natural environment [7]. Small and medium enterprises (SMEs) play important roles around the globe economically, environmentally, and socially. They not only provide excellent services at affordable prices, but also help rural and backward areas for poverty alleviation, thus reducing regional inequality and ensuring equal distribution of national income and resources [8]. It is believed that SMEs can have a significant social impact as they have good understanding of their stakeholders. Hence, the SME sector does not fall outside the purview of CSR and perhaps this is the reason that, today, researchers and policy makers, all around the globe, are paying considerable attention towards the contribution of the SME sector to reduce the level of environmental dilapidation.

SMEs play an important role in many economies, especially in developing countries. SMEs report on many businesses around the world and make a significant contribution to job creation and economic development around the world. They represent $90 \%$ of the world's businesses and more than $50 \%$ of the employment. SMEs contribute up to $40 \%$ to gross domestic product (GDP) in developing economies. These numbers are very high when informal SMEs are also involved. According to an estimation of World Bank, 600 million jobs will be needed by 2030, making SMEs development a priority for many governments around the world, as most of the jobs in emerging markets are created by SMEs, which is 7 out of 10 jobs [9].

SMEs concentrate about $90 \%$ of the total number of entrepreneurs in Pakistan and their share in annual GDP is up to $40 \%$, and exports to Pakistan are about $30 \%$. SMEs are spread in all regions of Pakistan, which has significantly improved in Punjab (65.4\%), Baluchistan (2.3\%), Sindh (18\%), and Khyber Pakhtunkhwa (14.3\%). Research shows that SMEs not only affect GDP, they also help to improve the lives of people by creating economic opportunities [10]. However, their environmental impact is also important, for example, in the European region, SMEs are estimated to account for $64 \%$ of total industrial pollution [11]. Similarly, toxic chemicals have been found in Pakistan to pollute water and air, leading to poor health, affecting local communities, and harming marine life. After recognizing the environmental impact of SMEs on the ecosystem and achieving the goals of sustainable development, various stakeholders encourage SMEs to reduce their impact on the environment [12].

The Global Climate Risk Index has placed Pakistan in fifth place in the list of nations most susceptible to climate change in its 2020 annual report. Pakistan lost the lives of 9989 people, incurred economic losses of $\$ 3.8$ billion, and faced a shocking 152 climates between 1999 and 2018. Based on this information, it is established that Pakistan's susceptibility to climate change is growing faster than ever before [13]. Pollution from industrial sector is one of the biggest problem in Pakistan. Industrial pollution is particularly damaging human health and the environment. In addition to automobile emissions, which accounts for $45 \%$ of pollution, industrial pollution is a major cause of environmental degradation in Pakistan [14]. Pakistan's industrial segment is widespread, with chemicals, 
electrical goods, plastic industry, textiles, fertilizers and other products, base metals, nonmetals, cement, automobiles, and light/heavy engineering. These production processes generate harmful air pollution, fumes, and dusts [15].

Unfortunately, there is little understanding of pollution prevention and improving pollution control in industry, especially in the SME sector. Current socio-environmental indicators and other related figures are worrying and unexpected. Pakistan is one of the 12 countries in Asia, which has a total of 15 countries, with high levels of industrial pollution. Every year, more than 6.5 million people are hospitalized due to pollution caused by industrial operations [16]. These figures paint a bleak picture of the future and calls for emergency measures taken especially in SME sector, to mitigate the intensity of environment degradation. In this regard, proactive approach of SMEs to adopt CSR activities may be a helpful coping strategy to reduce the effect of climate change.

There have been different studies in contemporary literature on CSR barriers in the context of both developed and developing countries. However, the point to note here is that there is no universal agreement on the list of barriers among the researchers to date. Furthermore, it is also not clear from the exiting literature which barriers may be of prime importance for a developing country like Pakistan. The extant literature has produced mixed results in this context; for instance, Goyal and Kumar [17] conducted a study on the identification of CSR barriers in India, and they mentioned that lack of financial resources is the most important barrier that restrict organizations in adopting CSR programs. Likewise, researchers like Hossain and Alam [18] contended that is the lack of institutional reforms that is a contributing CSR barrier in the context of a developing nation like Bangladesh. Furthermore, the researchers from Taiwan produced another result indicating that lack of CSR strategy is the root cause in restricting enterprises from practicing CSR activities in the Airline industry [19]. In the same vein, a recent study from Malaysia in the SME sector revealed that the lack of CSR training is the barrier that stands in the way of SMEs to practice a CSR program [20]. The above results clearly indicate that the findings in the literature about the hierarchy of CSR barriers are mixed with respect to a specific culture and country, which clearly highlights that there is need to understand and identify the hierarchy of barriers in the context of Pakistan, the place of the present study.

The concept of CSR is complex and contextual in nature, and perhaps this is the reason that, in different settings and contexts, CSR activities produce different outcomes. Due to its complexity and highly contextual nature, there is no universally accepted definition of CSR, hence it is not without logic to investigate the importance of CSR in specific settings and cultures. Most of the research on barriers to the CSR of SMEs are based on cross-sectional data showing the owners/managers a list of barriers with a rating scale on which they are asked to respond to a specific barrier $[19,21,22]$. However, this significantly limits the depth of analysis. First, it is based on ideas that do not correspond to real experience. Second, it provides policy limitations because it does not identify specific areas of the problem. Likewise, quantitative studies have long explained different CSR barriers in emerging economy context but, to date, it is evident that SMEs' contribution towards environmental cause has not improved significantly. This is perhaps due to one possible reason that the phenomenon of CSR is contextually and culturally dependent, hence it requires a detailed understanding of CSR barriers in specific cultural settings. With this in mind, the present study's approach is to conduct qualitative survey through semi-structured interviews with a relatively small sample of business representatives of SMEs in Pakistan. This reveals a great in-depth of analysis, for better insight for policy makers.

\section{Materials and Methods}

The concept of CSR has evolved at different stages since the 1950s, but it is still a broad, multifaceted concept consisting of actions against various business monopolies and requiring a definition on which a universal consensus is built [21,22]. However, according to Carroll [22], social responsibility means something, but it is not always the same for everyone. To others, it means the idea of legal responsibility or liability; for others, it means 
that we have to behave socially. CSR is actually acknowledged as a contextual concept based on organizations and specific characteristics, which makes CSR a complex concept and difficult to define unanimously $[22,23]$.

According to Carroll [5], CSR consists of four main elements: Economic, legal, ethical, and philanthropic. Davies and Crane [24] defined ethical, legal, and economic factors as the main priorities of any CSR activity. Dahlsrud [25] identified that there are five key dimensions of CSR, including environmental, social, economic, stakeholder, and voluntary action dimensions. The five-factor CSR model presented by Dahlsrud [25] corresponds to the standard CSR model of Carroll [2], in which economic, legal, and ethical domains are the same as those identified by Dahlsrud [25], and environment may fall under legal if it is obligatory by state laws or voluntary if state laws do not restrict it. Corporate economic responsibility is defined as productive and efficient and meets the needs of the community. The legal liability of the business indicates that economic liability must be considered in legal terms. Responsibility for business ethics reflects unwritten codes, customs, and values from society and, as a result, goes beyond the legal framework. Philanthropic activities can affect the perception and attitude of customers and affect the reputation of the company, which brings great benefits. Charity is not commercial, but brings both benefits and social status [26]. Charity is primarily about fundraising, but the power to contribute is based on the religious beliefs of SMEs' managers/owners in several countries. SMEs represent a large sector in the world economy [27]. SMEs are seen as a platform for job creation [28] that provides business mechanisms, while large businesses are formally involved and familiar with CSR activities. Research shows that SMEs are not socially responsible formally, and use informal CSR methods [29,30]. Typically, SMEs networks help identifying social issues and possible ways to address a number of social issues, such as making a financial contribution to society as a whole, building corporate value, and responding to stakeholders [31]. However, the role of SMEs, mostly in developing regions of the world, has been passive towards CSR programs. Contemporary literature also acknowledges that there are different barriers that restrict SMEs in developing countries to practice CSR proactively $[17,18]$. Table 1 presents the hierarchy of different CSR barriers extracted from contemporary literature.

Table 1. The hierarchy of corporate social responsibility (CSR) barriers in multiple sectors.

\begin{tabular}{|c|c|c|c|}
\hline No. & Hierarchy of CSR Barriers & Sector & Source \\
\hline 1 & $\begin{array}{l}\text { "lack of top management commitment" } \\
\text { "lack of financial resources" } \\
\text { "lack of knowledge about CSR practices" } \\
\text { "lack of effective strategic planning for CSR" } \\
\text { "absence of significant benefits for CSR } \\
\text { implantation" } \\
\text { "complexity of CSR implementation" }\end{array}$ & SME & $\begin{array}{l}\text { Goyal and Kumar } \\
\text { [17] }\end{array}$ \\
\hline 2 & $\begin{array}{l}\text { "lack of CSR training" } \\
\text { "financial resources" }\end{array}$ & SME & $\begin{array}{c}\text { Norbit, Nawawi and } \\
\text { Salin [20] }\end{array}$ \\
\hline 3 & $\begin{array}{l}\text { "fear of bureaucracy" } \\
\text { "administrative burden" }\end{array}$ & SME & Apospori [32] \\
\hline 4 & $\begin{array}{l}\text { "CSR awarness" } \\
\text { "environmental laws" }\end{array}$ & Construction & Bevan and Yung [33] \\
\hline 5 & $\begin{array}{l}\text { "financial constraints" } \\
\text { "lack of customer awareness" } \\
\text { "lack of regulations and standards" } \\
\text { "lack of top management commitment" } \\
\text { "lack of social audit" } \\
\text { "lack of stakeholder awareness" }\end{array}$ & Textile & Shen, et al. [34] \\
\hline
\end{tabular}


Table 1. Cont.

\begin{tabular}{|c|c|c|c|}
\hline No. & Hierarchy of CSR Barriers & Sector & Source \\
\hline 6 & $\begin{array}{l}\text { "lack of resources" } \\
\text { "lack of regulations and standards" } \\
\text { "lack of policy incentives" } \\
\text { "government policy" }\end{array}$ & Manufacturing & Bux, et al. [35] \\
\hline 7 & $\begin{array}{l}\text { "attributes of CSR" } \\
\text { "stakeholder perspective" } \\
\text { "commitment from top management" }\end{array}$ & Constructions & Zhang, et al. [36] \\
\hline 8 & $\begin{array}{l}\text { "marketing demand of CSR" } \\
\text { "CSR training and skills" }\end{array}$ & Automobile & Balon, et al. [37] \\
\hline 9 & $\begin{array}{l}\text { "high cost of CSR initiatives" } \\
\text { "insufficient knowledge" } \\
\text { "lack of top management commitment" }\end{array}$ & $\begin{array}{l}\text { Different } \\
\text { sectors }\end{array}$ & $\begin{array}{l}\text { Chojnacka and } \\
\text { Wiśniewska [38] }\end{array}$ \\
\hline 10 & $\begin{array}{l}\text { "shareholders value maximization" } \\
\text { "political barriers" }\end{array}$ & $\begin{array}{l}\text { Different } \\
\text { sectors }\end{array}$ & Nwoke [39] \\
\hline
\end{tabular}

The priority of the business is assumed to be wealth and profit goals in line with legislation, but businesses should be concerned about ethics. Theoretical perspective provides a description of the factors that motivate companies to develop their own CSR activities. Hamid, et al. [40] identify four broad perspectives for supporting theories. The first theoretical group in CSR is called the "CSR tool", in which all social actions of business are accepted only if they contribute to the process of wealth creation, for example, organizational strategies that can be equitable and competitive [41]. The second set of theories is called "political ideology", in which the organization accepts a certain level of human rights and activities and participates in a certain level of social cooperation; for example, the theory of integrated citizenship and the theory of social harmony [42]. The third group of theories is called "integrated theory", in which business is assumed to be dependent on society for its growth and beliefs, and it is important for business to integrate social needs; for example, theories of social productivity and stakeholder management [43]. The last set of theories highlights the ethical reasons for the relationship between business and the community, and emphasizes that businesses should accept CSR as a moral obligation: The theory of environmental rights and sustainable development [44] There are different theories to support CSR, including institutional theory, agency theory, stewardship theory, stakeholder theory, and resource-based view (See Table 2).

Table 2. Supporting theories of CSR.

\begin{tabular}{|c|c|}
\hline Theory & Description \\
\hline Institutional theory & $\begin{array}{c}\text { Social institutions are imperative to establish a moral code for } \\
\text { organizations }[45,46]\end{array}$ \\
\hline Stewardship theory & $\begin{array}{l}\text { CSR is regarded as a set of moral values to be practiced in businesses } \\
\text { without considering its relationship with performance [47] }\end{array}$ \\
\hline Agency theory & $\begin{array}{c}\text { CSR is an outcome of self-serving behavior of management at } \\
\text { shareholders' expense [48] }\end{array}$ \\
\hline Stakeholder theory & $\begin{array}{l}\text { CSR is principally the outcome of developing associations with } \\
\text { actors/entities which are affected or can affect the businesses [49] }\end{array}$ \\
\hline Resource based view & $\begin{array}{c}\text { CSR is regarded as a potential capability that can generate } \\
\text { competitive advantage [50] }\end{array}$ \\
\hline
\end{tabular}

The present study uses the theoretical lens of resource-based view (RBV) and institutional theory, which are referred to underpinning theories for present research. It is logical to use these theoretical lenses simultaneously as the previous literature confirms this approach [51-53]. A resource-based perspective can identify the scarcity of internal resources of SMEs that impede their ability towards environmental improvement, and institutional theory can be used to assess the organizational level forces outside the or- 
ganizational sphere to prevent environmental degradation. Therefore, these theoretical lenses are helpful to simultaneously assess the internal and external factors influencing the environmental impact of SMEs. Moreover, like all other economic sectors, the SME sector is also becoming highly competitive due to stiff competitive environment that pertain in almost every sector of the business [54].

Resource-Based View (RBV) originates primarily from the work of Wernerfelt [55]. However, its origins can be traced back to 1959 in the work of Penrose [56], who described the organization as a tool and the role of management in the manufacture and use of existing equipment to generate financial outputs. He argues that the resources are a guarantee of strong growth. Therefore, in order to grow, companies need to maximize their resources. Next, Wernerfelt [55] discusses the resources as the tools that prevent rivals from getting better financial returns. Therefore, RBV argues that valuable and irreplaceable resources can make the organization more efficient and competitive. However, if a company does not have the necessary resources, it will not always be able to compete in the market [57]. Institutional theory is one of the most widely used approaches in the field of management sciences [58]. This is an important theory for considering the influence of external forces on the structure and behavior of organizations. In general, the theory states that different players in a company's settings put pressure on businesses to change their behavior, programs, and strategies to ensure their survival. Therefore, companies are supposed to meet the expectations of the organizational sector, i.e., they should adapt to changes in the environment to achieve human health and well-being [59-61]. However, this is possible only if the organizational setting is strong enough to cause significant stress and, in some cases, provide the necessary support to players in the organizational settings. Therefore, when responding to changes and pressures in an organization's settings, organizations can receive a wide variety of responses ranging from calm to rebuilding this stress. Oliver [62] revised the tough responses in five categories: Confession, compromise, restraint, disgust, and hypocrisy. Responding to confession and compromise requires meeting the needs of the organization without excessive demand, restraint, disgust, and hypocrisy means a more reactive response, i.e., avoiding organizational stress.

There is no specific definition of SMEs that is universally accepted. All the definitions are based on convenience and objectivity of the study [63]. SMEs are the organizations with no more than 250 workers. Different countries define SMEs differently. It has different definitions in manufacturing and service sector [64]. In the context of Pakistan, SMEs are defined as the business unit with maximum 250 employees, paid capital of 25 million, and annual sales not exceeding 250 million [63]. Generally, it can be said that the enterprises that have less capital and manpower are considered to be SMEs. SMEs play a vital role for the progress of any economy, especially for the less developed countries. These countries use SMEs to boost their exports and turn their economies into successful economies [65]. During the past two decades, SMEs played a vital role in the developing economies. That is why Pakistan also needs to enhance its exports through SME sector keeping in view the current circumstances [65]. In Pakistan, SMEs share in all the business organizations is $90 \%$ and they employs more than $70 \%$ of the labor force. SMEs are contributing in almost all the sectors of the economy in Pakistan. Even though SMEs contribute a lot to the economy, little research has been conducted on it [63] to show how important SMEs are for Pakistan's economy.

The factors that create obstacles or hindrance in the implementation of a system are called barriers. Researchers have identified many barriers to CSR in different sectors. The critical barriers to CSR include: Lack of top management commitment towards CSR [17], lack of CSR knowledge [17,66], lack of resource [17,67-69], complexity of CSR issues [17,68]; lack of regulations [70], high cost of CSR initiatives [71], lack of effective strategic planning [17], customers' passive behavior towards CSR [17]. The identification and removal of these barriers can help SMEs to achieve effective results in CSR implementation. These are some of the barriers identified, which are also mentioned in Table 3. 
Table 3. Common barriers to CSR implementation.

\begin{tabular}{|c|c|c|}
\hline No. & Barriers & Literature Sources \\
\hline 1 & $\begin{array}{l}\text { Lack of top management } \\
\text { commitment }\end{array}$ & $\begin{array}{l}\text { Lenssen, et al. [72]; Goyal and Kumar [17]; Raut, } \\
\text { Narkhede, Gardas and Luong [66]; Yuen and Lim } \\
\text { [70]; Faisal [73]; Bux, Zhang and Ahmad [35] }\end{array}$ \\
\hline 2 & Lack of CSR knowledge & $\begin{array}{c}\text { Goyal and Kumar [17]; Raut, Narkhede, Gardas and } \\
\text { Luong [66]; Kumar and Dixit [74]; Yuen and Lim } \\
\text { [70]; Zhang, Oo and Lim [36] }\end{array}$ \\
\hline 3 & Lack of resources & $\begin{array}{c}\text { Goyal and Kumar [17]; Lincoln [67]; Bello and } \\
\text { Kamanga [68]; Puppim de Oliveira and Jabbour [69]; } \\
\text { Lenssen, Blagov, Bevan, Arevalo and Aravind [72]; } \\
\text { Yuen and Lim [70] }\end{array}$ \\
\hline 4 & Complexity of CSR issues & $\begin{array}{l}\text { Goyal and Kumar [17]; Lenssen, Blagov, Bevan, } \\
\text { Arevalo and Aravind [72]; Hsu and Cheng [75]; } \\
\text { Kitada and Ölçer [76] }\end{array}$ \\
\hline 5 & Lack of regulations & $\begin{array}{c}\text { Yuen and Lim [70]; Lenssen, Blagov, Bevan, Arevalo } \\
\text { and Aravind [72]; Bux, Zhang and Ahmad [35]; } \\
\text { Sajjad, et al. [77] }\end{array}$ \\
\hline 6 & $\begin{array}{l}\text { The high cost of CSR } \\
\text { initiatives }\end{array}$ & $\begin{array}{c}\text { Alotaibi, Edum-Fotwe and Price [71]; Lincoln [67]; } \\
\text { Zhang, Oo and Lim [36] }\end{array}$ \\
\hline 7 & $\begin{array}{l}\text { Lack of effective strategic } \\
\text { planning }\end{array}$ & $\begin{array}{l}\text { Goyal and Kumar [17]; Zhang, Oo and Lim [36]; } \\
\text { Bello and Kamanga [68] }\end{array}$ \\
\hline 8 & $\begin{array}{l}\text { Customers' passive behavior } \\
\text { towards CSR }\end{array}$ & Goyal and Kumar [17]; Li, et al. [78] \\
\hline
\end{tabular}

\section{Methodology}

The present study chooses qualitative approach in order to capture deeper insights about CSR barriers in SME sector of Pakistan. The qualitative research approach is interpretative in nature and it places significant importance to the subjectivity in comparison to quantitative research that is objective in nature [79]. Moreover, the qualitative approach enriches the in-depth understanding about a specific phenomenon [80]. Further, unlike the quantitative approach, the qualitative approach challenges a phenomenon by looking into it with a different lens, which is unusual in quantitative studies [81]. The ontology of qualitative research is that there exist multiple realities for a particular phenomenon and individuals perceive and interpret the phenomenon based on their own experience and knowledge [82]. The qualitative approach is best suited to understand a phenomenon from a deeper perspective, which is not possible in quantitative research studies.

Qualitative surveys are characterized by flexibility, transparency, and openness to the specific context; the steps in data collection and analysis are not as rigid and consistent as in quantitative surveys. Hence in qualitative research, sampling, data collection, analysis, and interpretation are iterative with each other in a circular pattern, not in a linear sequence. The researcher can take information about the choice of method, how they are made, and what and how many units are used. As shown in Figure 1, this research strategy may involve an interacting step between data collection and analysis, which may lead to the harmonization and expansion of the original plan. Some information is required to design the research question and/or the entire research plan. The process ends when it is complete, i.e., when there is no new relevant information which is left behind. For transparency, this is important for all documented and valid reasons. Most research on barriers to the CSR in SMEs is based on cross-sectional data showing the owner/manager a list of barriers with a rating scale on which they are asked to respond to a specific barrier. However, this significantly limits the depth of analysis. First, it is based on ideas that do not correspond to real experience. Second, it provides policy limitations because it does not identify specific areas of the problem. Hence, the present study's approach is to conduct qualitative survey through semi-structured interviews with a small sample of business representatives of SMEs in Pakistan. This reveals a great in-depth analysis, for a better insight to policy makers. For doing so, the data collection process was split into two phases. 
In the first phase, a list of above-stated barriers was sent to the senior management of SMEs (CEO, MD, owner, managers etc.) to ask the suitability of CSR barriers; in this regard, almost 100 persons from different sectors of SMEs in Lahore were approached for seeking their opinion regarding the suitability of listed barriers. After receiving data, we assessed whether the list of barriers remained the same or we have to drop/add some barriers based on the insights from SMEs' representatives. The initial assessment showed that most of the informants stayed with five barriers, including lack of resources, lack of regulations, lack of top management commitment, lack of CSR knowledge, and passive customer behavior towards CSR.

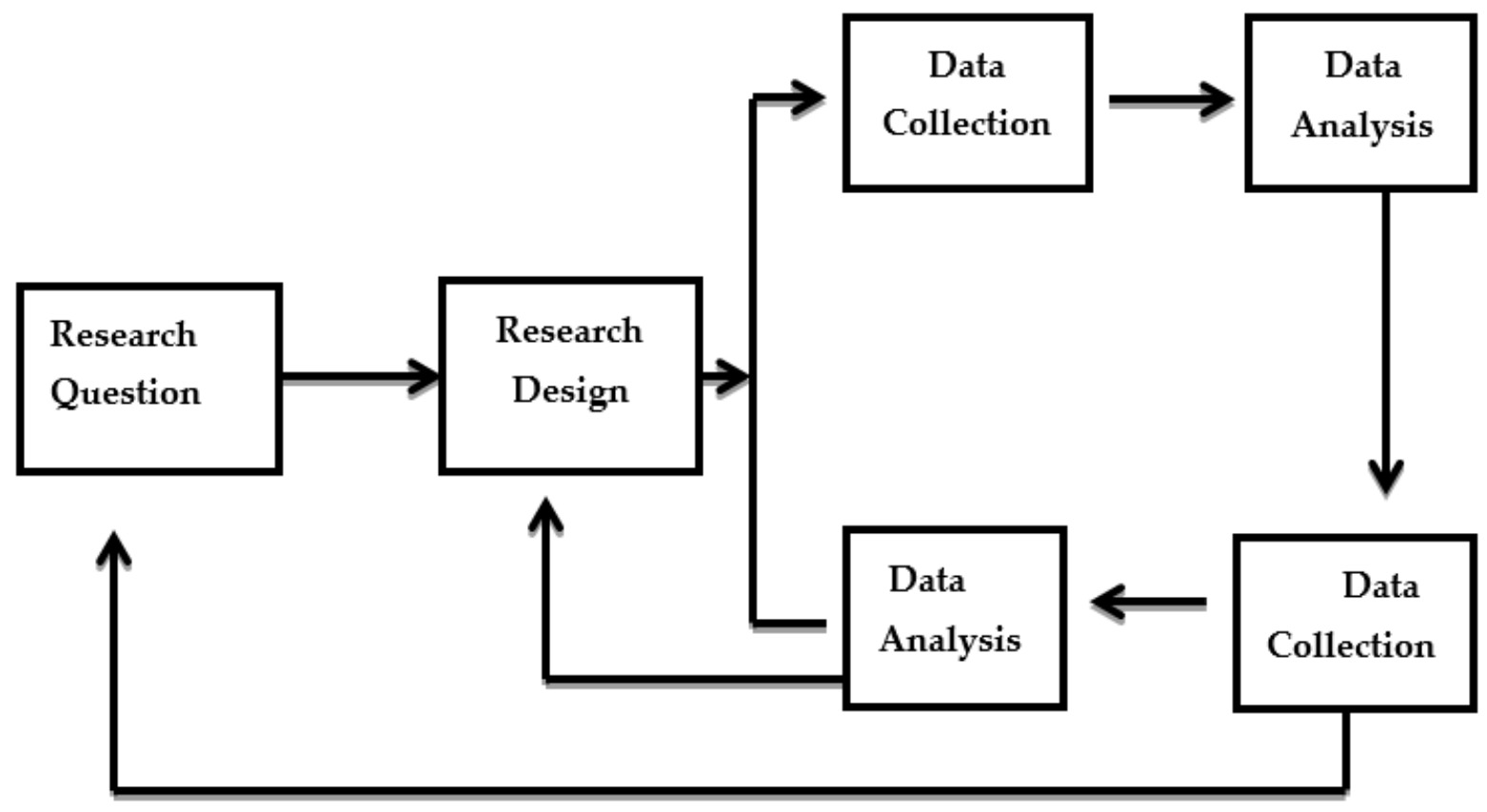

Figure 1. The iterative qualitative research process.

Finally, we conducted in-depth interviews in 9 SMEs from Lahore city of Pakistan, which is an industrial hub of the country. The total interview duration ranges from $30 \mathrm{~min}$ to $40 \mathrm{~min}$. The interviews were conducted in English and Urdu (at the convenience of respondents). In this regard, we carefully developed interview template after analyzing different CSR barriers from the existing literature. The interview questions were adapted from the study of Agyemang, et al. [83], which are listed in Appendixes B and C. For data analysis purposes, we used thematic content analysis to identify thematic patterns within an interview. The authors carefully selected illustrative quotes and themes in order to assure reliability into thematic analysis. These extracted themes were cross-checked in order to avoid any ambiguity. In order to maintain anonymity of the participants, we mentioned all SMEs with numeric (SME1, SME2, SME3, etc.). These steps for thematic analysis are in line with the recommendations of Braun and Clarke [84], and Bello and Kamanga [68].

\section{Results and Findings}

The thematic analysis of the present study showed that there are different barriers that hinder SMEs' attempts to implement CSR initiatives. We extracted from interviews a total of five themes that restrict SME sector of Pakistan to be involved proactively in CSR activities. These include: (1) Lack of resources; (2) lack of regulations and government support; (3) lack of top management commitment; (4) lack of CSR knowledge; (5) passive customer behavior towards CSR. 


\subsection{Lack of Resources}

The majority of the interviewees mentioned that lack of resources, especially financial resources, are the key constraints to CSR implementation. The majority of SMEs showed that they are willing to invest in environmental cause, but due to certain resources-related barriers, they find difficult to implement CSR initiatives, as indicated by different SMEs during interview:

'Our organization (SME) does not have sufficient resources to invest in CSR initiatives, as we belong to small scaled business, sparing financial resources for CSR activities is cumbersome for our organization ... (SME1)'

'The biggest issue with our setup to go with CSR initiatives are limited resources. If we have better resources, we will happily invest into CSR ... (SME4)'

'We want to apply new technologies for better energy production to reduce the level of negative impact on environment due to our operations. But the problem is, applying new technologies are too costly to bear for a small setup like ours ... . ... (SME5)'.

The interviewees expressed the opinion that if they would have sufficient resources, they would proactively participate into sustainability initiatives. Although some SMEs were taking some minor CSR initiatives, such as donations to poor employees or donating some finance to outside community for charity purpose, the majority of the participants argued that resource constraints one of the major reason for their negligence towards environment. This barrier was recognized as the most critical by the participants to the present study. This barrier is also in line with the findings of previous researchers like Goyal and Kumar [17], Lenssen, Blagov, Bevan, Arevalo and Aravind [72], and Bux, Zhang and Ahmad [35].

\subsection{Lack of Regulations and Government Support}

The interview session also revealed that poor environmental regulations along with no or little support from government is a major constraint. For example, one participant shared his views:

'The part of government to support us for CSR initiatives is very poor, likewise there are no specific regulations that govern SME sector for environmental dilapidation (SME3)'

'I don't remember any event in which our political setup supported or encouraged us for our CSR initiatives. The negligence of government attention towards a clear policy framework for SME sector to preserve the environment and community, further aggravate the situation. I don't know any SME belonging to our sector which is involved in CSR disclosure reporting (SME4)'.

The government of Pakistan should devise a clear policy framework to encourage CSR participation from small- and medium-sized businesses in order to increase their participation towards CSR activities. Furthermore, the government should also take some meaningful initiatives to support CSR practices of SME sector, for example governments should conduct different seminar and training regarding the importance of CSR activities. Likewise, the government needs to support SME sector to access the latest technologies for manufacturing purpose that are eco-friendly. In this regard, some financial support at the part of government may produce a significant result. The barrier "lack of regulation and governmental support" is also acknowledged as a hurdle for CSR practices in the existing literature, such as Goyal and Kumar [17], Bello and Kamanga [68], and Luo, et al. [85]. Despite government support, there is still a need for strict environmental laws regarding the SME sector of Pakistan. It is worth mentioning that such laws to protect the environment would have an appreciable impact only if truly enforced, because much of the progress thus far in Pakistan has mostly been on paper. 


\subsection{Lack of Top Management Commitment}

Another barrier indicated by the participants in this study was the lack of senior management commitment towards CSR activities, as explained by participants:

'Yes, I must say that most of the time our senior management do not consider CSR as an important concern and they show a passive behavior towards CSR initiatives, because they think investing in CSR is the responsibility of larger businesses and we are small players, hence we need not to worry about our contribution to upgrade the environment (SME1)'

'Whenever I highlighted to my top management about our contribution towards society and environment, I received little or no attention in this regard. Mostly our management say "Ok we will look into this matter in future" or "this time we are facing other problems, first we have to solve those problems" (SME2).

There is a misconception in most top management of SMEs that investing in CSR is not in their benefit, because it is volunteer activity, and therefore we should leave it to the shoulder of big businesses [84]. This barrier is also acknowledged by extant researchers $[17,86,87]$. This is the time to change the behavior of management of SMEs in Pakistan, as they need to realize that the responsibility of CSR belongs to everyone, regardless of how large or how small the size of business is. Until or unless this lack of commitment from senior management in SME sector ceases, the hope to achieve a better sustainable future will remain only a hope, with no real results.

\subsection{Lack of CSR Knowledge}

The participants of the study also mentioned that most of their workers have little knowledge about CSR activities and what it contributes collectively for society and environment, as one participant mentioned it as:

'People over here are not well familiar with the notion of CSR, this is disappointing that we live in digital age, developed countries are taking CSR activities to an advance level to address different social and environmental issue. Unfortunately, here in our setup, most people have no or little knowledge about CSR activities and its potential for society and environment (SME8)'

'Workforce here, do not know the long-term benefits of CSR activities. This is a potential barrier to our organization which demotivate us from practicing CSR at each level of our organization (SME7)'.

Lack of knowledge about CSR initiative is the fourth obstacle to achieve sustainability objectives in SMEs, as indicated by participants during in-depth interviews. This barrier is also highlighted by different researchers in existing CSR literature $[19,21,34]$. There is a daunting need to upgrade the CSR awareness at all levels in the country. Pakistan needs to learn from the experience of western economies where one of the prominent drivers of sustainable practices from enterprises is the pressure from different stakeholders, such as consumers and competitors. This pressure can be built on business if the level of CSR awareness is mature enough among the ranks and files of the country. Furthermore, the increased awareness level is a doubl-edged sword, which not only creates pressure on business from stakeholders, but also motivates the enterprises to voluntarily take part in different CSR programs.

\subsection{Customers' Passive Behavior towards CSR}

Lastly, the participants' responses also supported that, due to customers' passive behavior towards CSR activities, the majority of SMEs in Pakistan is not motivated to adopt CSR program proactively. Respondents stated their view regarding this barrier as:

'Your question is interesting, but dare me to say that none of our customers ask us to go for sustainable practices. They are just concerned with product related outputs and 
give no importance the process through which it is produced or what kind of harm it is producing for environment (SME6)'

'Workforce here, do not know the long-term benefits of CSR activities. This is a potential barrier to our organization which demotivate us from practicing CSR at each level of our organization (SME7).'

Customers' passive behavior is another potential barrier that restricts SMEs to practice CSR activities in this sector. In developed countries, this barrier is one of the top rated barriers, but in developing countries settings, like Pakistan, it is rated last in the list of barriers and this is logical because most people in Pakistan have little knowledge about sustainability or CSR practices. This is also in line with the argument of Goyal and Kumar [17] who contend that customers in developing countries have very little knowledge about CSR and hence they put little or no pressure on businesses to get engaged in sustainable practices. The overall hierarchy extracted from thematic analysis is shown in Figure 2.

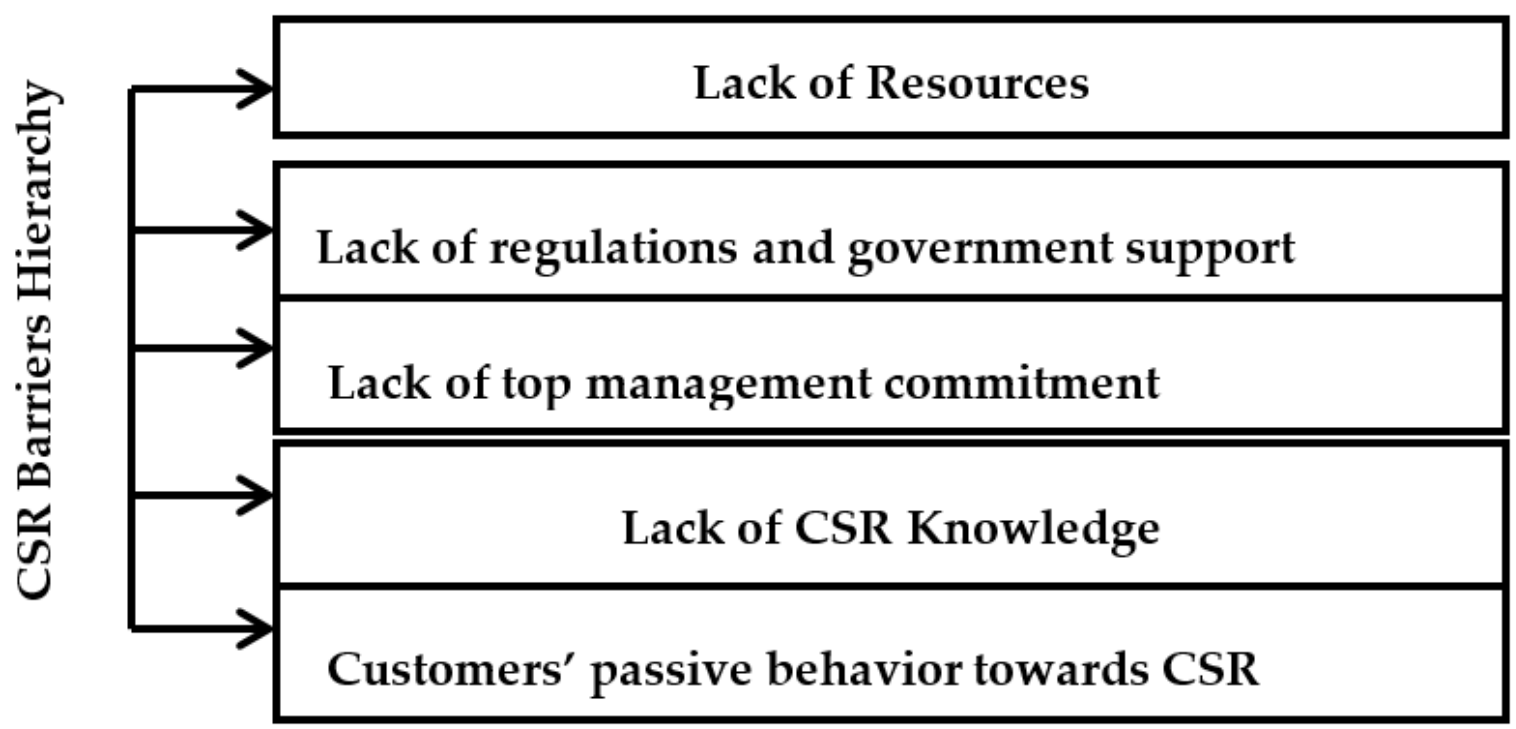

Figure 2. Hierarchy of CSR Barriers: This figure shows the hierarchy of CSR barriers that is derived from the findings of in-depth interviews of the present study.

\section{Implications}

The presents study highlights different CSR barriers in the context of SME sector of Pakistan. In this regard, five themes were extracted from an in-depth analysis of the interviews. The findings of the present study have some important implications for policy makers. To begin with, the SME sector of Pakistan in its present state is not participating in CSR activities proactively due to different barriers. For example, the interviewees of the present study largely mentioned that lack of resources is one of the biggest issues hindering their participation in CSR activities. To address this issue, different steps may be taken at the government level, for instance, government should encourage the SME sector to participate in CSR activities through helping them financially, by providing easy loans that are dedicated to being invested for environmental causes. It is worthy to mention here that until government starts to play an active role to increase the participation from SME sector of Pakistan for CSR activities, it will remain a dream to urge SMEs to change their behavior towards CSR practices.

Another important implication of the present study is that our study sheds light on weak government regulations and lack of support for the SME sector in the context of environment. As indicated by the informants, they receive no strict rulings from government to ask them to practice a CSR plan. There are some surface level rules and regulations, but 
these rules appear only in documents, their true implementation does not exist in Pakistan. In this connection, the government needs to take necessary actions and devise some specific laws pertinent to environment. Informants of this study also highlighted that they received no support from government for CSR initiatives. In this regard, the government is suggested to work in close coordination with SMEs' representatives to devise a crush plan for appreciating CSR participations from this sector; for example, governments may announce some tax rebates for those SMEs that truly practice CSR activities to upgrade society and environment. Such initiatives will provide a kind of motivation for SME sector of Pakistan to strategically invest into environmental cause.

Top management ignorance is another barrier that came to the surface as a result of the present study. Most of the informants indicated that they receive less attention from senior management towards CSR initiatives. They also highlighted that most of their senior management shows passive behavior towards implementation of CSR activities because they feel that they are small business players and the responsibilities of CSR initiatives do not belong to them and hence they leave such initiatives to be taken by large businesses. There is a dire need to change this overall behavior of top management towards CSR initiatives. One possible solution to address the situation may be to conduct different seminars and trainings in the field of CSR by different government institutions to highlight the importance of CSR for SMEs and to change their mistaken belief that CSR activities are largely relevant to large business players.

Lack of CSR knowledge as a barrier towards CSR implementation is also a contributing factor that hinders SMEs to practice CSR initiatives. This situation can be improved through intensive education programs that aim to build the CSR knowledge of employees working in different sector of SMEs in Pakistan. One thing to be mentioned here is that without upgrading the knowledge, it is almost impossible to change the behavior of SME sector towards CSR initiatives, because in present settings, unfortunately they are largely unaware of the devastating effects of their operations towards society and environment.

Lastly, the informants also mentioned that they barely receive any pressure from their customer to initiate any CSR program in their organizations. This is understandable and logical because, unfortunately, in real sense, CSR is still at its infancy stage in Pakistan. In comparison to developed countries, where customers are big players to put pressure on businesses to be actively involved in sustainable practice, the customers in Pakistan neither give importance to such initiatives nor they think about it while making their purchase decisions. This situation may be improved through intensive education related to CSR initiatives. One possible solution may be to include CSR literature into the curriculum of schools and higher education institutions.

\section{Conclusions}

The present study highlights different barriers in the context of SME sector of Pakistan. Unlike the quantitative studies in the field of CSR, the present study helps policy makers and scholars to build a thorough understanding of why SME sector of Pakistan is reluctant to practice CSR activities. The study is different from previous studies because it produces different results, for example the present study indicates that lack of resources is the biggest issue that restricts SME sector from implementing CSR initiatives, whereas in other settings, different studies placed other CSR barriers at the top to implement CSR activities. It is logical to observe different results, because, as we stated earlier, the concept of CSR is highly contextual and produces different results in different contexts.

Although, by 2020, the concept of CSR in Pakistan still remains unclear due to lack of CSR awareness among rank and files of the country. This is quite a recent in Pakistan that businesses have to invest in social responsibility. Most of the organizations in Pakistan invest in the philanthropic domain of CSR, because businesses in Pakistan mostly assume that CSR is concerned with philanthropic activities like sponsoring in education, donating for charity, establishing water tanks for the public, etc. However, the environmental domain 
of CSR is largely unattended by the businesses in Pakistan. In a nutshell, the concept of CSR, even in 2020, is mostly associated with volunteer efforts to support the community.

The SME sector of Pakistan faces different challenges, which hinder in their way to be engaged into CSR initiatives. Particularly, our study mentioned five thematic extractions, including lack of resources, weak regulation, top management ignorance, lack of CSR knowledge, and passive customer behavior as the barriers to implement CSR activities. Through the lenses of institutional theory and resource based view, we are able to understand that, due to certain constraints and resources deficiency, the SME sector of Pakistan is reluctant to respond to CSR initiatives proactively. There are some SMEs that participate in CSR activities at smaller level, for example donating in charity and providing some financial support to employees, but largely they assume that CSR initiatives are majorly concerned with large businesses. The findings of the present study will help policy makers to work on the ways through which the barriers mentioned in this study may be removed in order to enhance the participation of SME sector of Pakistan in the field of CSR.

Pakistan Environmental Protection Agency (PEPA) is the premier institution in Pakistan which work to preserve natural environment in Pakistan. PEPA was established in 1997, but since its establishment, its real contribution to save the environment is almost non-existent, because mostly interventions taken by PEPA for environment protection only appear on paper, not in reality. However the rise of widespread pollution and changing climatic condition in the country have pushed the government officials and PEPA authorities to take some real steps to mitigate the environmental footprint of industries. Hence, in 2012, PEPA framed first climate change policy in Pakistan, but due to certain political upsets in the country, this policy also remained passive until 2016. Presently, there are some real interventions taken by PEPA to frame environmental laws for industries in order to mitigate their environmental hazards. In this connection, there is a lot of work that is yet to be done by at the part of government and businesses to hope for a better and sustainable future of the country.

Like other studies, the present study at hands also faces some limitations that open new horizons for upcoming researchers in the same field. To start with, the present research study is an initial attempt to understand different barriers that SME sector of Pakistan is facing presently; the point to mention here is that we only conducted interviews from a limited number of organizations in a concentrated geographical area. The upcoming researchers in the field are encouraged to repeat the study with a larger sample of organizations and a more diverse geographical area, which may include different cities.

Further, there is a need to explore the phenomenon of CSR in other contexts, for example, the service sector including the banking sector and the healthcare sector, because the insight from other sectors will further enrich our understandings about CSR in the context of Pakistan. Moreover, in this study, we only invited representatives from different SMEs, but it is important to note that the viewpoint of government officials in this regard may be very important to gain an even deeper understanding about the issue at hand. In this connection, we urge future researchers to take the insight from government officials so that a deeper, more diverse, and better understanding can be made.

Author Contributions: All authors have contributed equally to all sections of this manuscript. All authors have read and agreed to the published version of the manuscript.

Funding: This research received no external funding.

Informed Consent Statement: Informed consent was obtained from the respondents of the survey.

Data Availability Statement: The data will be made available on request from corresponding author.

Conflicts of Interest: The authors declare no conflict of interest. 


\section{References}

1. Carroll, A.B.; Laasch, O. From managerial responsibility to CSR and back to responsible management. In Research Handbook of Responsible Management; Edward Elgar Publishing: Cheltenham, UK, 2020.

2. Carroll, A.B. A history of corporate social responsibility: Concepts and practices. In The Oxford Handbook of Corporate Social Responsibility; Oxford University Press: Oxford, UK, 2008; pp. 19-46. [CrossRef]

3. Bowen, H.R.; Johnson, F.E. Social Responsibility of the Businessman; Harper: New York, NY, USA, 1953.

4. WBCSD. World Business Council for Sustainable Development. Available online: www.wbcsd.org (accessed on 11 November 2020).

5. Carroll, A.B. A three-dimensional conceptual model of corporate performance. Acad. Manag. Rev. 1979, 4, 497-505. [CrossRef]

6. Ben Youssef, K.; Leicht, T.; Pellicelli, M.; Kitchen, P.J. The importance of corporate social responsibility (CSR) for branding and business success in small and medium-sized enterprises (SME) in a business-to-distributor (B2D) context. J. Strateg. Mark. 2018, 26, 723-739. [CrossRef]

7. Ye, N.; Kueh, T.-B.; Hou, L.; Liu, Y.; Yu, H. A bibliometric analysis of corporate social responsibility in sustainable development. J. Clean. Prod. 2020, 272, 122679. [CrossRef]

8. Wu, G.C. Effects of socially responsible supplier development and sustainability-oriented innovation on sustainable development: Empirical evidence from SMEs. Corp. Soc. Responsib. Environ. Manag. 2017, 24, 661-675. [CrossRef]

9. World Bank. Small and Medium Enterprises Finance. Available online: https://www.worldbank.org/en/topic/smefinance (accessed on 18 November 2020).

10. Nadeem, A.; Kakakhel, S.J. An exploratory evidence of practice, motivations, and barriers to corporate social responsibility (CSR) in small and medium enterprises (SMEs) of Khyber Pakhtunkhwa Pakhtunkhwa (KPK). Abasyn J. Soc. Sci 2016, 9, 479-494.

11. OECD. SMEs: Key Drivers of Green and Inclusive Growth. Available online: www.oecd.org (accessed on 18 November 2020).

12. Waseem, A.; Arshad, J.; Iqbal, F.; Sajjad, A.; Mehmood, Z.; Murtaza, G. Pollution status of Pakistan: A retrospective review on heavy metal contamination of water, soil, and vegetables. BioMed Res. Int. 2014, 2014, 1-29. [CrossRef]

13. Germanwatch. Global Climate Risk Index 2020. Available online: www.germanwatch.org (accessed on 19 October 2020).

14. Siddique, H.M.A.; Kiani, A.K. Industrial pollution and human health: Evidence from middle-income countries. Environ. Sci. Pollut. Res. 2020, 27, 1-10. [CrossRef]

15. Mahmood, M.T.; Shahab, S.; Hafeez, M. Energy capacity, industrial production, and the environment: An empirical analysis from Pakistan. Environ. Sci. Pollut. Res. 2020, 27, 4830-4839. [CrossRef] [PubMed]

16. Ajmal, M.M. Industrial pollution in Pakistan. Available online: https://nation.com.pk (accessed on 4 November 2020).

17. Goyal, P.; Kumar, D. Modeling the CSR barriers in manufacturing industries. Benchmarking Int. J. 2017, 24. [CrossRef]

18. Hossain, M.M.; Alam, M. Corporate social reporting (CSR) and stakeholder accountability in Bangladesh. Int. J. Account. Inf. Manag. 2016, 24, 415-442. [CrossRef]

19. Kuo, T.C.; Kremer, G.E.O.; Phuong, N.T.; Hsu, C.-W. Motivations and barriers for corporate social responsibility reporting: Evidence from the airline industry. J. Air Transp. Manag. 2016, 57, 184-195. [CrossRef]

20. Norbit, N.; Nawawi, A.; Salin, A.S.A.P. Corporate social responsibility practices among the smes in malaysia-A preliminary analysis. Manag. Account. Rev. (Mar) 2017, 16, 17-40. [CrossRef]

21. Yuen, K.F.; Lim, J.M. Barriers to the implementation of strategic corporate social responsibility in shipping. Asian J. Shipp. Logist. 2016, 32, 49-57. [CrossRef]

22. Agudo-Valiente, J.M.; Garcés-Ayerbe, C.; Salvador-Figueras, M. Corporate social responsibility drivers and barriers according to managers' perception; Evidence from Spanish firms. Sustainability 2017, 9, 1821. [CrossRef]

23. Roszkowska-Menkes, M. What does CSR really stand for? An analysis of corporate definitions of CSR in Poland. Pr. Nauk. Uniw. Ekon. We Wroctawiu 2016, 94-106. [CrossRef]

24. Carroll, A.B. Carroll's pyramid of CSR: Taking another look. Int. J. Corp. Soc. Responsib. 2016, 1, 1-8. [CrossRef]

25. Kölbel, J.F.; Busch, T. Signaling legitimacy across institutional contexts-The intermediary role of corporate social responsibility rating agencies. Glob. Strategy J. 2019. [CrossRef]

26. Davies, I.A.; Crane, A. Corporate social responsibility in small-and medium-size enterprises: Investigating employee engagement in fair trade companies. Bus. Ethics A Eur. Rev. 2010, 19, 126-139. [CrossRef]

27. Dahlsrud, A. How corporate social responsibility is defined: An analysis of 37 definitions. Corp. Soc. Responsib. Environ. Manag. 2008, 15, 1-13. [CrossRef]

28. Kim, M.; Yin, X.; Lee, G. The effect of CSR on corporate image, customer citizenship behaviors, and customers' long-term relationship orientation. Int. J. Hosp. Manag. 2020, 88, 102520. [CrossRef]

29. Kim, J.S.; Milliman, J.; Lucas, A. Effects of CSR on employee retention via identification and quality-of-work-life. Int. J. Contemp. Hosp. Manag. 2020, 32. [CrossRef]

30. Chege, S.M.; Wang, D. Information technology innovation and its impact on job creation by SMEs in developing countries: An analysis of the literature review. Technol. Anal. Strateg. Manag. 2020, 32, 256-271. [CrossRef]

31. Grimstad, S.M.F.; Glavee-Geo, R.; Fjørtoft, B.E. SMEs motivations for CSR: An exploratory study. Eur. Bus. Rev. 2020 32. [CrossRef]

32. Aras-Beger, G.; Taşkın, F.D. Corporate Social Responsibility (CSR) in Multinational Companies (MNCs), Small-to-Medium Enterprises (SMEs), and small businesses. In The Palgrave Handbook of Corporate Social Responsibility; Palgrave: London, UK, 2020; pp. 1-25. 
33. Jamali, D.; Lund-Thomsen, P.; Jeppesen, S. SMEs and CSR in developing countries. Bus. Soc. 2017, 56, 11-22. [CrossRef]

34. Zhang, Q.; Oo, B.L.; Lim, B.T.H. Drivers, motivations, and barriers to the implementation of corporate social responsibility practices by construction enterprises: A review. J. Clean. Prod. 2019, 210, 563-584. [CrossRef]

35. Apospori, E. Regional CSR policies and SMEs' CSR actions: Mind the gap-The case of the tourism SMEs in crete. Sustainability 2018, 10, 2197. [CrossRef]

36. Bevan, E.A.; Yung, P. Implementation of corporate social responsibility in Australian construction SMEs. Eng. Constr. Archit. Manag. 2015, 22. [CrossRef]

37. Shen, L.; Govindan, K.; Shankar, M. Evaluation of barriers of corporate social responsibility using an analytical hierarchy process under a fuzzy environment-A textile case. Sustainability 2015, 7, 3493-3514. [CrossRef]

38. Bux, H.; Zhang, Z.; Ahmad, N. Promoting sustainability through corporate social responsibility implementation in the manufacturing industry: An empirical analysis of barriers using the ISM-MICMAC approach. Corp. Soc. Responsib. Environ. Manag. 2020, 27, 1729-1748. [CrossRef]

39. Balon, V.; Sharma, A.K.; Barua, M.K. Assessment of barriers in green supply chain management using ISM: A case study of the automobile industry in India. Glob. Bus. Rev. 2016, 17, 116-135. [CrossRef]

40. Chojnacka, E.; Wiśniewska, J. Reporting CSR Data-the benefits and barriers to involvement in the idea of corporate social responsibility. J. Posit. Manag. 2017, 8, 3. [CrossRef]

41. Nwoke, U. Corporations and development: The barriers to effective corporate social responsibility (CSR) in a neoliberal age. Int. J. Law Manag. 2017, 59, 122-146. [CrossRef]

42. Hamid, S.; Riaz, Z.; Azeem, S.M.W. Carroll's dimensions and CSR disclosure: Empirical evidence from Pakistan. Corp. Gov. Int. J. Bus. Soc. 2020, 20. [CrossRef]

43. Currás-Pérez, R.; Dolz-Dolz, C.; Miquel-Romero, M.J.; Sánchez-García, I. How social, environmental, and economic CSR affects consumer-perceived value: Does perceived consumer effectiveness make a difference? Corp. Soc. Responsib. Environ. Manag. 2018, 25, 733-747. [CrossRef]

44. Jiang, F.; Zalan, T.; Herman, H.; Shen, J. Mapping the relationship among political ideology, CSR mindset, and CSR strategy: A contingency perspective applied to Chinese managers. J. Bus. Ethics 2018, 147, 419-444. [CrossRef]

45. Marques-Mendes, A.; Santos, M.J. Strategic CSR: An integrative model for analysis. Soc. Responsib. J. 2016, 12, 363-381. [CrossRef]

46. Beniulytè, D.; Šeinauskienè, B.; Rūtelionè, A. Perceived influence of corporate social responsibility on consumer loyalty: The role of ethical ideology. Entrep. Sustain. Issues 2020, 8, 291-300. [CrossRef]

47. Aggarwal, V.S.; Jha, A. Pressures of CSR in India: An institutional perspective. J. Strategy Manag. 2019, 12. [CrossRef]

48. Espinoza-Ramos, G.R. 'Unwritten Rules' in Social Partnerships: Defining Corporate Social Responsibility (CSR) Through Institutional Theory in the Peruvian Mining Industry. In Responsible Business in a Changing World; Springer: Berlin, Germany, 2020; pp. 235-245.

49. Cossin, D.; Smulowitz, S.; Lu, A. Stewardship focus, monitoring, executive pay, and their effects on CSR: A content analysis approach. Acad. Manag. Proc. 2020, 2020, 12166. [CrossRef]

50. Li, F.; Li, T.; Minor, D. CEO power, corporate social responsibility, and firm value: A test of agency theory. Int. J. Manag. Financ. 2016, 12, 611-628. [CrossRef]

51. Theodoulidis, B.; Diaz, D.; Crotto, F.; Rancati, E. Exploring corporate social responsibility and financial performance through stakeholder theory in the tourism industries. Tour. Manag. 2017, 62, 173-188. [CrossRef]

52. Kofford, S.; Clark, A.; Jones Christensen, L.M. Barriers to imitation in strategic CSR: Organizational authenticity and the resource-based view. Acad. Manag. Proc. 2020, 2020, 21329. [CrossRef]

53. Advantage, C. Corporate social responsibility. Csr Soc. Responsible Investig. Strateg. Transit. Emerg. Econ. $2020,65$.

54. Nair, A.K.; Bhattacharyya, S.S. Mandatory corporate social responsibility in India and its effect on corporate financial performance: Perspectives from institutional theory and resource-based view. Bus. Strategy Dev. 2019, 2, 106-116. [CrossRef]

55. Frynas, J.G.; Yamahaki, C. Corporate social responsibility: Review and roadmap of theoretical perspectives. Bus. Ethics A Eur. Rev. 2016, 25, 258-285. [CrossRef]

56. Valeri, M. Networking and cooperation practices in the Italian tourism business. J. Tour. Herit. Serv. Mark. 2016, 2, 30-35.

57. Wernerfelt, B. A resource-based view of the firm. Strateg. Manag. J. 1984, 5, 171-180. [CrossRef]

58. Penrose, E. The Theory of the Growth of the Firm; John Wiley and Sons. Inc.: New York, NY, USA, 1959.

59. Khan, S.N. Making sense of the black box: An empirical analysis investigating strategic cognition of CSR strategists in a transitional market. J. Clean. Prod. 2018, 196, 916-926. [CrossRef]

60. Zhao, E.Y.; Fisher, G.; Lounsbury, M.; Miller, D. Optimal distinctiveness: Broadening the interface between institutional theory and strategic management. Strateg. Manag. J. 2017, 38, 93-113. [CrossRef]

61. Scott, W.R. The adolescence of institutional theory. Adm. Sci. Q. 1987, 32, 493-511. [CrossRef]

62. Tina Dacin, M.; Goodstein, J.; Richard Scott, W. Institutional theory and institutional change: Introduction to the special research forum. Acad. Manag. J. 2002, 45, 45-56. [CrossRef]

63. Peters, B.G. Institutional Theory in Political Science: The New Institutionalism; Edward Elgar Publishing: Cheltenham, UK, 2019.

64. Oliver, C. Strategic responses to institutional processes. Acad. Manag. Rev. 1991, 16, 145-179. [CrossRef] 
65. Saleem, I.; Siddique, I.; Akmal, A.; Khan, M.S.M.; Khan, M.U.; Sultan, S.; Khan, M.S.M. Impact assessment of ISO 9000 series on the organizational performance: Empirical evidence from small and medium enterprise (SME) sector of Pakistan. Afr. J. Bus. Manag. 2011, 5, 10885-10892.

66. Syed, A.; Ahmadani, M.M.; Shaikh, N.; Shaikh, F.M. Impact analysis of SMEs sector in economic development of Pakistan: A case of Sindh. Res. Publ. 2012, 2, 44-53.

67. Berry, A.; Aftab, K.; Qureshi, S.K. The potential role of the SME sector in Pakistan in a world of increasing international trade [with comments]. Pak. Dev. Rev. 1998, 25-49. [CrossRef]

68. Lenssen, G.; Blagov, Y.; Bevan, D.; Arevalo, J.A.; Aravind, D. Corporate social responsibility practices in India: Approach, drivers, and barriers. In Corporate Governance: The international Journal of Business in Society; Emerald Publishing: Bradford, UK, 2011; Volume 11, pp. 399-414.

69. Raut, R.; Narkhede, B.E.; Gardas, B.B.; Luong, H.T. An ISM approach for the barrier analysis in implementing sustainable practices. Benchmarking Int. J. 2018, 25. [CrossRef]

70. Lincoln, A. Corporate social responsibility in Nigeria: Drivers and barriers experienced by female entrepreneurs when undertaking CSR. In Stages of Corporate Social Responsibility; Springer: Berlin, Gemany, 2017; pp. 25-45.

71. Bello, F.G.; Kamanga, G. Drivers and barriers of corporate social responsibility in the tourism industry: The case of Malawi. Dev. South. Afr. 2020, 37, 181-196. [CrossRef]

72. Puppim de Oliveira, J.A.; Jabbour, C.J.C. Environmental management, climate change, CSR, and governance in clusters of small firms in developing countries: Toward an integrated analytical framework. Bus. Soc. 2017, 56, 130-151. [CrossRef]

73. Hsu, J.L.; Cheng, M.C. What prompts small and medium enterprises to engage in corporate social responsibility? A study from Taiwan. Corp. Soc. Responsib. Environ. Manag. 2012, 19, 288-305. [CrossRef]

74. Alotaibi, A.; Edum-Fotwe, F.; Price, A.D. Critical barriers to social responsibility implementation within mega-construction projects: The case of the Kingdom of Saudi Arabia. Sustainability 2019, 11, 1755. [CrossRef]

75. Faisal, M.N. Analysing the barriers to corporate social responsibility in supply chains: An interpretive structural modelling approach. Int. J. Logist. Res. Appl. 2010, 13, 179-195. [CrossRef]

76. Kumar, A.; Dixit, G. An analysis of barriers affecting the implementation of e-waste management practices in India: A novel ISM-DEMATEL approach. Sustain. Prod. Consum. 2018, 14, 36-52. [CrossRef]

77. Kitada, M.; Ölçer, A. Managing people and technology: The challenges in CSR and energy efficient shipping. Res. Transp. Bus. Manag. 2015, 17, 36-40. [CrossRef]

78. Sajjad, A.; Eweje, G.; Tappin, D. Sustainable supply chain management: Motivators and barriers. Bus. Strategy Environ. 2015, 24, 643-655. [CrossRef]

79. Li, Y.; Pinto, M.C.B.; Diabat, A. Analyzing the critical success factor of CSR for the Chinese textile industry. J. Clean. Prod. 2020, 260, 120878. [CrossRef]

80. Elliott, D.; Husbands, S.; Hamdy, F.C.; Holmberg, L.; Donovan, J.L. Understanding and improving recruitment to randomised controlled trials: Qualitative research approaches. Eur. Urol. 2017, 72, 789-798. [CrossRef]

81. Valeri, M.; Baggio, R. Social network analysis: Organizational implications in tourism management. Int. J. Organ. Anal. 2020. early release. [CrossRef]

82. Valeri, M.; Baggio, R. Italian tourism intermediaries: A social network analysis exploration. Curr. Issues Tour. 2020, 1-14. [CrossRef]

83. Willis, D.G.; Sullivan-Bolyai, S.; Knafl, K.; Cohen, M.Z. Distinguishing features and similarities between descriptive phenomenological and qualitative description research. West. J. Nurs. Res. 2016, 38, 1185-1204. [CrossRef]

84. Agyemang, M.; Kusi-Sarpong, S.; Khan, S.A.; Mani, V.; Rehman, S.T.; Kusi-Sarpong, H. Drivers and barriers to circular economy implementation. Manag. Decis. 2019, 57. [CrossRef]

85. Braun, V.; Clarke, V. Using thematic analysis in psychology. Qual. Res. Psychol. 2006, 3, 77-101. [CrossRef]

86. Luo, J.M.; Huang, G.Q.; Lam, C.F. Barriers to the implementation of corporate social responsibility in gaming industry. J. Qual. Assur. Hosp. Tour. 2019, 20, 528-551. [CrossRef]

87. El-Bassiouny, D. Corporate social responsibility (CSR) and the developing world: Highlights on the Egyptian case with implications for CSR education. In Ethics, CSR and Sustainability (ECSRS) Education in the Middle East and North Africa (MENA) Region; Routledge: Abingdon, UK, 2020; pp. 34-50. 